\title{
The Privatization of International Security
}

\author{
Leander, Anna
}

Document Version

Final published version

Publication date:

2009

License

CC BY-NC-ND

Citation for published version (APA):

Leander, A. (2009). The Privatization of International Security. Department of Intercultural Communication and Management, Copenhagen Business School.

Link to publication in CBS Research Portal

\section{General rights}

Copyright and moral rights for the publications made accessible in the public portal are retained by the authors and/or other copyright owners and it is a condition of accessing publications that users recognise and abide by the legal requirements associated with these rights.

Take down policy

If you believe that this document breaches copyright please contact us (research.lib@cbs.dk) providing details, and we will remove access to the work immediately and investigate your claim. 


\title{
WORKING PAPER
}

\author{
2009, nr. 10 \\ Monday, 30 November 2009
}

The Privatization of International Security

by Anna Leander

Professor (mso)

Department of Intercultural Communication and Management Porcelænshaven 18 A, DK-2000 Frederiksberg Copenhagen Business School 


\begin{abstract}
The integration of private international security into Security Studies reflects the relatively recent nature of the market. The literature on the topic revolves around the basics of placing private international security on the agenda (1a); explaining and understanding the market (1b) and problematizing its relationship to central questions in international security (1c). The current trend in the field is to face the-still largely open — challenge of taking research further, both by completing, refining and updating current research efforts (2a) and by expanding and enriching the research agenda to more fully explore the politics of market development (2b). Paradoxically, as this entry concludes, this is leading scholars to abandon the focus on "privatization" and instead pushing them to formulate research agenda in new terms such as commercialization, commodification, governance or governmentality.
\end{abstract}




\section{The Privatization of International Security}

By Anna Leander (ale.ikl@cbs.dk)

\section{Working Paper:}

Forth coming in The Routledge Companion to Security Studies

Edited by Myriam Dunn Cavelty and Victor Mauer (London and New York: Routledge) 


\section{Introduction and Overview: PMSCs and International Security}

The privatization of international security could refer to a wide range of phenomena reflecting the growing role of non-state actors in international security. This Handbook's entries on New Wars, Terrorism, State Failure, Migration, Organized Crime, or Energy Security could be read as reflections on "the privatization of international security". This entry will not replicate their arguments or try to cover privatization in this broad sense. Rather, it will explore privatization in the more specific sense of the word, namely as referring to the incidence or process of transferring ownership, control or competencies from the public sector (state) to the private sector (business); in this case within the realm of International Security. It will in other words deal with the development of a market for force and with the private military and security companies (PMSCs) operating in it, looking at how these have become part of security studies.

PMSCs are companies that buy and sell military and security services internationally. Their activities encompass logistics, intelligence, consultancies, training, and protection services. What ties them together is that they take on tasks that armed forces also can or do take on and that this directly ties them to the use of force. Since many contemporary conflicts are not international, this use of force might not be strictly speaking "military" but may fall within the "security" realm, hence the importance of talking about PMSCs rather than just PMCs. In fact, companies (particularly those providing protection such as Blackwater) insist on defining their activities as falling in the security realm to avoid association with mercenarism. As many other markets, the market for force is highly segmented; with companies specializing in different activities, catering for specific demands and (hence) having varied relations to clients and following different formal (laws, regulations) and informal (codes of conduct, norms) rules. ${ }^{1}$

Estimates (more akin to wild guesses) have conveyed the rapid and recent expansion and growth of the market. The private military sector reportedly doubled in size between 1990 and 1999 ( $\$ 55$ to $\$ 100$ bn.) and is expected to double again by 2010 (reaching $\$ 200 \mathrm{bn}$.). The increased ratio of contractors to US soldiers. It said to have been 1-60 in the 1991 Gulf war and to have become 1,3-1 in Iraq 2007. At the same time a growing number of (heavily mediatized) incidences involving PMSCs have come to epitomize their presence in public discussions. Few will have remained unaware for example of the death of 17 Iraqi civilians shot by Blackwater employees in Baghdad in 2007, the “Trophy” video showing Aegis employees shooting at random while "driving in Iraq" in 2004, the involvement of TITAN and CACI employees in the abuse of Abu Ghraib inmates in 2003/4, the lynching of four Blackwater employees in Fallujah in 2004, or the role of Executive Outcomes in the Sierra Leonean civil war 1995-6.

The integration of private international security into Security Studies reflects the relatively recent nature of the market. The literature on the topic revolves around the basics of placing private international security on the agenda (1a); explaining and understanding the market (1b) and problematizing its relationship to central questions in international security (1c). The current trend in the field is to face the - still largely open—challenge of taking research further, both by completing, refining and updating current research efforts (2a) and by expanding and enriching the research agenda to more fully explore the politics of market development (2b). Paradoxically, as this entry concludes, this is leading scholars to abandon the focus on "privatization" and instead pushing them to formulate research agenda in new terms such as commercialization, commodification, governance or governmentality.

\footnotetext{
${ }^{1}$ This entry could be spent entirely on defining and describing the sector. But since this is not the aim see the relevant overview chapters in Avant 2005, Leander 2006, Singer 2003 or Isenberg 2007.
} 


\section{Key Themes}

Work on the privatization of security expresses the recent nature of the phenomenon. It evolves around the basic need of attracting attention to the significant developments that have taken place since the end of the cold war, to affirm its general political salience and of course also to show that it is a topic worthy scholarly attention. Much of this work is not strictly academic. Practionners have had strong reasons to push for more engagement with private international security. This section sketches out the key themes in the resulting literature.

\section{a. Discovering/Denouncing/Documenting Private Intermational Security}

If this Handbook had been written 10 years ago, this entry would almost certainly not have been included. This is partly because the market expanded radically only after the end of the cold war. But it is also because conventional security studies and international relations refused (and in many camps still refuse) to acknowledge its significance, reducing firms to prolongations of states and denying the existence of markets. As a consequence a recurrent issue in the literature about private international security has been establishing its existence and relevance.

Non-academic work by journalists, think tanks, advocacy NGOs, security professionals (including members of armed forces and the private security sector) has played a key role in the documenting the significance of the market. Their closeness to the practice of security makes them acutely aware of changing role of markets and PMSCs. It also directly implicates them with the various problems and prospect inherent in market development. Business professionals and their professional associations have documented the part private security plays in a number of conflicts and suggested ways of using it more constructively (Spicer, Barlow, London, IPOA and BAPSC). Lawyers from the armed forces have documented the role of "contractors on the battle field" and pressed for clarifications of what can be demanded of them and what responsibility the armed forces have towards them (Guillory, Heaton, Zamparelli). Political activists have raised concerns about the issues of political and legal accountability when war becomes business (ICIJ, Musah and Fayemi). Public accountants have scrutinized the existing systems of economic accountability (GAO, Bauman and Rasor). Human rights activists and lawyers have debated the degree to which markets raise human rights concerns and how these might be dealt with (ICRC, War on Want, Human Rights First). Finally, journalists working in conflict areas and/or with international security have pushed for greater awareness around the role of market and market actors (Silverstein, Pelton Young) as well as studied specific firms (Scahill), specific subsectors (Shorrock) or the specific conflicts (Fainaru).

The result is an extensive production on private international security driven by the concerns of those engaged in its practice. It is difficult to overstate the significance of this work for the development of the scholarly field. It has diffused information and details about a sector that can be difficult to access. It has done so in dialogue with the academic world providing "facts" and ideas about key issues and processes. Finally, the practionners engagement with private security has been key to public debate on the issue. Public awareness in turn has triggered a demand for scholarly work on the subject, ushered in funding for projects and legitimacy for research in the field. The consequence is that a degree rather uncommon in scholarly security studies-possibly reflecting more general transformations of knowledge production —-work on private international security is "problem driven"; formulated in dialogue with practionners who discover, document and denounce the sector.

\section{b. Explaining and Understanding Private International Security}

The academic pendant of the need to discover, docmument and denounce is to explain and understand. As academia has become increasingly engaged with private international security, a 
second focus therefore emerges: explaining and understanding private international security, including its origins, its workings and its government.

What made the development of private international security possible in the first place is an intriguing and interesting question. Why states would loosen up their control over the sensitive security sector and why professionals both in the formerly protected, heavily state subsidized military/security business and in the armed forces have welcomed and often encouraged its development are questions that figure prominently in the current academic literature on private international security. Arguments that recur in the answers include changing political conditions, and particularly the end of the cold, which drove states to diminish defense budgets and hence pushed security firms and professionals (unemployed professionals) to provide for themselves effectively creating a market (Cambridge Special Issue, Singer). More than this, region specific changes are often invoked in explanations. In Africa, for example, the end of apartheid left a large professional security force in search for alternative occupations. At the same time revisions in international development aid strategies and internal political alliance strategies made African states interested in market based security solutions (Abrahamsen special issue, Musah). Finally, changes in weapon technologies and the organization of armed forces; the revolution in military affairs and the associated use of "dual" and "off the shelf" technology as well as shifts in overarching governance patters—post-fordism and new public management - are suggested to have made less statist and more market oriented strategies seem inevitable also in the security sector (Kaldor et al., Markusen et al., Susman).

A second equally intriguing and difficult question that almost automatically follows from the previous one is how private international security works and particularly whether or not it is efficient. Is the market merely a shift in the way states do things and not really a private market at all with firms functioning as weapon systems in the hands of states (Shearer)? Or, are the firms genuinely private, working on in a private market with its own admittedly idiosyncratic norms and rules? Whether they are private or not, are these markets effective or-perhaps more adequately in view of the unraveling economic scandals - can they be made effective? What kind of institutions would it actually take to ensure that the markets proved capable of doing more than merely diverting the post-cold war peace dividend to those who were supposed to pay it (Cambridge special issue, Markusen, Singer)? These questions are not minor or narrowly economic ones. They are of intense political relevance since efficiency and cost savings have been pivotal in legitimizing outsourcing and privatization strategies everywhere. They also have ramifications into theoretical literature on organizational and governance structures in other areas and finally they very explicitly raise the question of how private international security is and should be governed.

To explain and understand the government of private international security is indeed a final central theme in existing scholarly work on private international security (Cateri, Chesterman). This should hardly come as a surprise since clarifying the relationship between markets and regulatory institutions is fundamental to understanding what firms can be held accountable for and where regulatory change is required — and politically feasible - to bring them under control (Coleman, Minow). This area is where academic and practionners interests overlap most directly and where line between the two is decidedly blurred. In the "mad scramble" (Kierpaul) to bring companies to justice a great number of publications in scholarly journals, in the form of commissioned reports and in form of advocacy papers have appeared to clarify, explain, and improve the possibilities of holding market actors accountable to civilians, their own employees, the states, armed forces, business, and institutions that contract them and inversely for ensuring that the companies have a possibility to demand accountability in return. These discussions have resulted not only in momentous progress in understanding of regulatory options, but also in growing clarity about where core disagreements and positions lie on how these can/should be used (de Wolf, Leander WP). Work explaining and 
understanding private international security has contributed far more to the clarification of disagreements than to production of consensus knowledge.

\section{c. Debating the Consequences of Private International Security}

A final key theme in the study of private international security has been the substantive implications of privatization for international security. The development of a private international security market poses real questions about the way security is organized, distributed and understood.

The state monopoly on the legitimate use of force is arguably at the heart of the organization of international security. It certainly underpins conventional thinking about international security where states are the main actors and assumed to have such a monopoly. Altering (e.g. by making more legitimate) or bolstering (by e.g. tightening control) the state monopoly on legitimate force therefore also figure centrally in debates about how to deal with international security problems. How privatization affects this monopoly on the use of force-and hence the organization of -international security consequently figures centrally in the study of private international security. Is one of the fundamental institutions of international society undergoing far reaching change or not? Have we seen a revision of the long standing strong norm/weak law banning mercenarism in international relations (Milliard, Percy). The answers span the full spectrum of possibilities. Some scholars depict a world where private international security has fundamentally undermined the SMLF by creating a world of legitimate security activities beyond the state; a new-medievalism or coming anarchy where companies compete with states. However, most scholars prefer to discuss transformations (Avant, Krahmann, Verkuil) and many suggest that state authority might in fact be rather untouched by the development of private international security since the centrality of sovereignty is not affected by it

(Thomson). Private international security might solidify the conventional organization of international security by rendering sovereignty and the SMLF even more central to international security relations. The market sharpens the divide between states who can bolster private international security to their own advantage and those that cannot not (Leander).

This evokes questions about what the development of private international security entails for the distribution of international security. Cui bono? The classical question has been a key bone of contention also in the discussions surrounding private international security. This question can of course be posed at the level of hierarchies among states as just indicated. Whose states security interests are served by the development of private international security and whose are not? For some private international security is above all the enabling condition of aggressive US/ Western unilaterialism (Tiefer) or of a form of corporate neo-imperialism allowing companies to govern economic activities and the territory necessary to that end (Francis, Musah). Either way, private international security exacerbates inequalities among states in the international system. For others, private international security is the condition which makes it possible for (some) weak and crumbling states to upgrade their armed forces and defend themselves against the spillovers from regional conflicts (Brooks, Howe). In this account, private international security bolsters weak states and hence diminishes inequality in the hierarchy among states.

Moving beyond the question of hierarchies among states to the level of whose security needs are served by the development of private international security, we again find sharply contrasting positions. Some scholars see private international security as the only alternative individuals, companies, NGOs and public institutions can avail themselves of when they operate in areas where public security has broken down (Abrahmsen, Cillers). They hence point out that this might compensate the obvious moral dilemma of embracing a system where only those in possession of the necessary financial means can ask for protection. Other scholars suggest that although this might be true at the individual level, it has the overall broader effect of further militarizing and securitizing 
social relations by increasing the presence, use and centrality of armed security. It hence leads to a deterioration of public security; not to its restoration (Cockayne, Leander, Spearin).

This leads straight to a final central theme in the study of private international security; its significance for security understandings, for the "construction" of threats and formulations of security strategies and politics. Does it matter that security is partly provided through markets for how threats are understood? The (often implicit) answer to this question particularly by those who advocate privatization but also by many other contributors to the discussions surrounding private international security is that companies respond to a given demand. They are "agents" of "principals"; when the military is involved the principal is usually a state while security services may be sold also to business, journalists and NGOs. The companies offer services to respond to predefined needs and threats; viz. a state contracting in private air-transport to transport soldiers or an NGO needing convoy protection in Afghanistan. The market does not define the threats. However, from a critical vantage point, it has been suggested that the companies actually re-shape security understandings as a part of their perfectly normal and legal activities for example through their consultancies, trainings, advertisements, routine practices, participation in public discussions: through the very basic fact that they promote security products they heighten awareness of insecurity and hence alter security perceptions (Der Derian, Leander, Lund-Petersen). This raises the more general question about whether or not there is a need to think about private security as a "contested commodity" on par with the trade in organs or prostitution where the strong moral and ethical stakes would warrant serious thinking about regulations on lobbying, public engagement, marketing and information about the sector (Sapone).

\section{Trends and Challenges ahead}

Just as the key themes in the study of private international security bear the mark of the recent nature of the field, so do the current research trends and challenges ahead. The basic needs of discovering, explaining and understanding basic aspects of private international security continue to play an important role and will do so for the foreseeable future. In addition to this, as the study of private international security is becoming more established the trend and challenge ahead is to refine and enrich the questions asked about it. Paradoxically (perhaps) this seems to be leading scholars away from the study of privatization.

\section{a. Filling the gaps}

Publications about private international security are mushrooming in all academic fields including in security studies. However, and in spite of this, there are major gaps in the basic knowledge and understanding of it. One trend at present is to close these gaps by looking at both at the many still under researched aspects of private international security and by integrating the constant evolution into the study area.

Writing about private international security has been rather narrow in its focus. It has been built largely around two empirical areas of study. The first is the role of private international security in the developing world. The reason is the central and much debated role of large private companies in key conflicts including for example the role of Executive Outcomes in Sierra Leone and Angola, of Sandline in Sierra Leone and Papua New Guinea (neither company exists today), of DynCorp in Colombia and of MPRI in Bosnia. The second is the role of large contractors to the US Armed Forces in Iraq and Afghanistan. This means that large swaths of private international security remain understudied. This is true of private international security outside the areas mentioned, including geographically notably private international security in Europe (Krahmann) but also in the developing world beyond the 1990s (Abrahamsen special issue). More than this, the focus on the large firms has 
meant that the role of smaller firms or firms working outside the highly mediatized conflicts has been largely left off the radar screens. The implication is that the vast subcontracting sector, the global employment practices and the ramifications of the global market remain ill understood. One of the current trends is therefore to expand the understanding of private international security in this direction (e.g. Abrahamsen and Williams).

Second, private international security is no fixed entity. On the contrary, the sizeable public debate and reflexivity about it makes it a dynamic and evolving area with constantly shifting and contested boundaries. The regulation and international standards governing private international security is developing rapidly as illustrated by changes in national and international regulation including the 2007 expansion of the US Uniform Code of Military Justice, the adoption of the ICRC Montreux Document, the changes occurring in the UN working group on mercenaries or shifting fates of the codes of conducted published e.g. by DCAF, IPOA and BASCP. More than this, governance is changing forms, particularly because of the steady growth of private sector involvement. Private security actors are to a growing extent taking part in various forms of private-public-partnerships and hybrid institutions governing private international security but also to a growing degree other realms including for example training policies or standard setting efforts (Dorn and Levi). Finally, the overarching logic for governing conducts (governmentality) in the security field, as in other areas, is increasingly "neo-l,iberal" (in the Foucauldian understanding); a trend that is both shaped by and shaping the privatization of security. Analyzing the meaning, implications and causes of these changes is a trend in writing (e.g. Leander, Salter).

Finally, scholars are enlargeing the kinds of questions asked of private international security. Projects are emerging on a wide range of central issues that have remained explored. One example is the relation of private international security to gender inside the market, among security professionals, but in society more broadly including both the home context of the companies and the places they operate (Schultz). This is but one example intended to underscore the trend to fill the gaps not only in knowledge but to open the field of private international security toward the study of a range of interesting issues

\section{b. Acknowledging the limitations of private international security}

The perhaps most interesting trend — and future challenge — is the critical evaluation of the limits inherent in a research agenda formulated around private international security.

One of the many established truths about private international security has been that the boundaries between states and markets are "blurred" and that the revolving doors at all levels are many. The spheres are for all purposes partly enmeshed. The practical implication has been that privatization understood as shifting ownerships, control and authority is difficult to establish. But perhaps even more significantly, the extent of overlap or enmeshment means that substantial political changes may take place without necessarily involving shifts in the formal private-public divide. Shifts for example in public discourses shaped by private international security advertising and lobbying, shifts in routine intelligence practices, or shifts in the hierarchies among security professionals linked to the growth of private international security may be of substantial political salience but entail no shifts in public-private authority. A discourse focusing on that divide may hence not only miss key political developments but also obscure them. The focus on the public-private divide distracts attention from critical inquiry and (thereby) bolsters the impression that private international security may have developed without significant political implications.

Scholars working on private international security have increasingly become (more or less articulately) aware of these drawbacks linked to a research agenda framed in terms of privatization. The consequence has been a trend to steer away from privatization and instead formulate research in terms that do not direct attention to the public or private status of actors but rather to the effects of 
creating security markets. Commodification, commercialization, governance and governmentality have come to figure more centrally on the research agenda. This move links studies of private international security more tightly to the broader "new" or "critical” security agenda. Questions surrounding the commercial production of new insecurities, the commercial refashioning of security spaces and the commercial everyday security practices figure prominently on this new research agenda (as elaborated in Leander 2009). The irony is that in their effort of gain leverage on the politics of private international security, researchers have had to confront the inherent limitations of an agenda focused on privatization: they have moved from studying the privatization of international security to the study of commercial insecurity. The reference list below is designed to give anyone interested in this field rapidly evolving field and its change plenty entry points for judging whether or not they agree with this depiction of the field and the many other claims advanced above.

\section{References and Links}

Useful weblinks:

The British Association of Private Security Companies (UK Based industry organization) http://www.bapsc.org.uk/

The Geneva Centre for the Democratic Control of Armed Forces programme on the Privatization of Security: http://www.privatesecurityregulation.net/introduction

The Institute for Security Studies (Pretoria ZA) privatization project

http://www.issafrica.org/index.php?link id=30\&link type=12\&tmpl id=2

The International Consortium of Investigative Journalists project on the business of war http://projects.publicintegrity.org/bow/

The International Peace institute database over researchers on international private security http://www.ipinst.org/our-work/coping-with-crisis/grips/

The International Peace Operations Association (US based industry organization)

http://ipoaworld.org/eng/

Private Military Org. Provides useful company links and links to literature

http://www.privatemilitary.org

All major firms run their own very instructive websites.

\section{Reports/Official Documents}

Brookings: Singer, Peter W. (2007) 'Can't Win with 'Em, Can't Go to War without 'Em: Private Military Contractors and Counterinsurgency'. Foreign Policy at Brookings. Policy Papers(4). (available at: http://www3.brookings.edu/papers/2007/0927militarycontractors.aspx )

GAO. (2008) 'Military Operations: Implementation of Existing Guidance and Other Actions Needed to Improve DOD's Oversight and Management of Contractors in Future Operations'. Washington D.C.: GAO (available at http://www.gao.gov/new.items/d08436t.pdf ). GAO produces a great number of relevant reports on US commercialization. Appendix 1 contains a list of reports related to this one. Human Rights First. (2008) Private Security Contractors at War: Ending the Culture of Impunity. (available at: www.humanrightsfirst.org ).

The Montreux Document: Promoted by the ICRC and now officially adopted by key contracting states including the US and the UK (available at www.icrc.org/web/eng/siteeng0.nsf/htmlall/montreux-document-170908)

The UN working group on the use of mercenaries... (see particularly the annual reports!) http://www2.ohchr.org/english/issues/mercenaries/wgstandards.htm 
War on Want: campaign against corporate mercenaries with a very useful report detailing the culture of impunity http://www.waronwant.org/Corporate+Mercenaries+13275.twl

\section{Monographs by journalists/insiders}

Barlow, Eeben. (2008) Executive Outcomes: Against All Odds: Galago Publishing.

Fainaru, Steve. (2008) Big Boy Rules: In the Company of America's Mercenaries Fighting in Iraq. Cambridge: Da Capo Press.

Isenberg, David. (2004) A Fistful of Contractors: The Case for a Pragmatic Assessment of Private Military Companies in Iraq (available at http://www.basicint.org/pubs/Research/2004PMC.htm ).

London, J. Phillipe and the CACI Team. (2008) Our Good Name: A Company's Fight to Defend its Honour and Get the Truth told About Abu Ghraib. Washington D.C.: Regenery Publishing.

Pelton, Robert Young. (2006) Licensed to Kill: Hired Guns in the War on Terror. New York: Crown Publishers.

Rasor, Dina and Bauman, Robert. (2007) Betraying Our Troops: The Destructive Results of Privatizing War. New York: Palgrave.

Scahill, Jeremy. (2007) Blackwater: The Rise of the World's Most Powerful Mercenary Army. Washington: Nation Books.

Shepherd, Bob. (2008) The Circuit: An Ex-SAS Soldier's True Account of One of the Most Powerful and Secretive Industries Spawned by the War on Terror London: Macmillan.

Shorrok, Tim. (2008) Spies for Hire: The Secret World of Intelligence Outsourcing. New York: Simon \& Schuster.

Spicer, Tim Lt Col. (1999) An Unorthdox Soldier: Peace and War and the Sandline Affair. Edinbrurgh: Mainstream.

\section{Academic Monographs, Edited Volumes and Articles}

Abrahamsen, Rita and Williams, Michael C. (2007) 'Special Issue: The Privatization and Globalisation of Security in Africa'. International Relations, 21(2).

Abrahamsen, Rita, and Michael C. Williams. (2006) The Globalization of Private Security: Country Reports for Kenya, Nigeria, Sierra Leone. Aberystwyth: University of Wales (available at: http://users.aber.ac.uk/rbh/privatesecurity/publications.html).

Avant, Deborah. (2005) The Market for Force: The Consequences of Privatizing Security. Cambridge: Cambridge University Press.

Brooks, Doug. (2000) Write a Cheque, End a War: Using Private Military Companies to End African Conflicts. Conflict Trends:33-35.

Cambridge Review of International Affairs. (1998) 'Special Issue on Private Military Companies'. Cambridge Review of International Affairs, XIII(1).

Carmola, Cateri. (2007) Private Military Companies and New Wars: Risk, Law \& Ethnics. London: Routledge

Chesterman, Simon and Lehnardt, Chia eds. (2007) From Mercenaries to Markets: The Rise and Regulation of Private Military Companies. Oxford: Oxford University Press.

Cockayne, James. (2006) 'Commercial Security in the Humanitarian Space'. International Peace Academy.

Coleman, James R. (2004) 'Constraining Modern Mercenarism'. Hastings Law Journal, 55(June):1493-537.

de Wolf, Antenor Hallo. (2006) 'Modern Condottieri in Iraq: Privatizing War from the Perspective of International and Human Rights Law'. Indiana Journal of Global Legal Studies, 13:315-56.

Der Derian, James. (2001) Virtuous War: Mapping the Military-Industrial-Media-Entertainment Network. Boulder CO.: Westview Press.

Dorn, Nicholas and Levi, Michael. (2007) 'European Private Security, Corporate Investigation and Military Services: Collective Security, Market Regulation and Structuring the Public Sphere'. Policing \& Society, 17(3):213-38. 
Dorn, Nicholas and Levi, Michael. (2007) 'Private-Public or Public-Private? Strategic Dialogue on Serious Crime and Terrorism in the EU'. Security Journal (August).

Francis, David J. (1999) 'Mercenary Intervention in Sierra Leone: Providing National Security or International Exploitation?' Third World Quarterly, 20(2):319-38.

Guillory, Major Michael E. (2001) Civilianizing the Force: Is the United States Crossing the Rubicon? The Air Force Law Review 51:111-42.

Haggerty, Kevin D. and Ericson, Richard V. (1999) 'The Militarization of Policing in the Information Age'. Journal of Political and Military Sociology, 27 (winter):233-55.

Heaton, J. Ricou. (2005) Civilians at War: Reexamining the Status of Civilians Accompanying the Armed Forces. Air Force Law Review 57:157-208.

Howe, Herbert M. (2001) Ambiguous Order: Military Forces in African States. Boulder CO.: Lynne Rienner

Kaldor, Mary, Albrecht, Ulrich and Schméder, Geneviève eds. (1998) Restructuring the Global Military Sector. The End of Military Fordism. London: Pinter.

Kierpaul, Ian. (2008) 'The Rush to Bring Private Military Contractors to Justice: The Mad Scrambel of Congress, Lawyers, and Law Students after Abu Ghraib'. The University of Toledo Law Review, 39:407-35.

Kinsey, Christopher. (2006) Corporate Soldiers and International Security: The Rise of Private Military Companies. London: Routledge

Krahmann, Elke. (2005) Controlling Private Military Companies in the UK and Germany: Between Partnership and Regulation. European Security 13:277-95.

Krahmann, Elke. (2007) 'Security: Collective Good or Commodity? ' European Journal of International Relations, 14(3):379-405.

Leander, Anna (WP) working papers on civil military relations, the impunity of contractors, international legal instruments of regulation and industry self images are available at www.cbs.dk/content/view/pub/38570.

Leander, Anna. (2005) 'The Market for Force and Public Security: The Destabilizing Consequences of Private Military Companies'. Journal of Peace Research, 42(5):605-22.

Leander, Anna. (2005) 'The Power to Construct International Security: On the Significance of Private Military Companies'. Millennium Journal of International Studies, 33(3):803-26.

Leander, Anna. (2006) Eroding State Authority? Private Military Companies and the Legitimate Use of Force. Rome: Centro Militare di Studi Strategici.

Leander, Anna. (2009) 'Securing Sovereignty by Governing Security through Markets', In Sovereignty Games: Instrumentalising State Sovereignty in Europe and Beyond, eds. Adler-Nissen, Rebbecca and Gammeltoft-Hansen, Thomas. London: Palgrave: 151-170.

Leander, Anna. (2009) Commercial Security Practices. In Handbook of New Security Studies, edited by Peter J. Burgess. London and New York: Routledge

Lynch, Tony and Walsh, A. J. (2000) 'The Good Mercenary'. Journal of Political Philosophy(8):13353.

Markusen, Ann R. (2003) 'The Case Against Privatizing National Security'. Governance: An International Journal of Policy, Administration, and Institutions, 16(4):471-501.

Markusen, Ann, DiGiovanna, Sean and Leary, Michael C. eds. (2003) From Defense to Development? International Perspectives on Realizing the Peace Dividend. London and New York: Routledge.

Milliard, Major Todd S. (2003) 'Overcoming Post-Colonial Myopia: A Call to Recognize and Regulate Private Military Companies'. Military Law Review, 1(8).

Minow, Martha. (2003) Public and Private Partnerships: Accounting for the New Religion. Harvard Law Review 116:1229-70.

Musah, Abdel-Fatau and Fayemi, Kayode J. eds. (2000) Mercenaries: An African Security Dilemma. London: Pluto Press.

Musah, Adel-Fatau. (2002) Privatization of Security: Arms Proliferation and the Process of State Collapse in Africa. Development and Change 33:911-33.

Percy, Sarah. (2007) 'Mercenaries: Strong Norm, Weak Law'. International Organization, 61(2):36797. 
Salter, Mark. (2008) 'Imagining Numbers: Risk, Quantification, and Aviation Security'. Security Dialogue, 39(2-3):243-66.

Sapone, Montgomery. (1999) 'I have rifle with Scope, will travel: The Global Economy of Mercenary Violence'. California Western International Law Journal, 30(fall):1-43.

Schultz, Sabrina, and Christina Yeung. (2008) Private Military and Security Companies and Gender March (available at: http://www.un-instraw.org/en/gps/security-toolkit/private-military-andsecurity-companies-and-g-2.html ).

Singer, Peter W. (2003) Corporate Warriors. The Rise of the Privatized Military Industry. Ithaca and London: Cornell University Press.

Singer, Peter W. (2007) 'Can't Win with 'Em, Can't Go to War without 'Em: Private Military Contractors and Counterinsurgency'. Foreign Policy at Brookings. Policy Papers(4).

Spearin, Christopher. (2008) 'Private, Armed and Humanitarian? States, NGOs, International Private Security Comapnies and Shifting Humanitarianism'. Security Dialogue, 39(4):363-82.

Susman, Gerald and O'Keefe, Sean eds. (1998) The defense industry in the post-Cold War era : corporate strategies and public policy perspectives: Pergamon.

Tiefer, Charles. (2007) 'The Iraq Debacle: The Rise and Fall of Procurement-Aided Unilateralism as a Paradigm of Foreign War'. University of Pennsylvania Journal of International Economic Law, 29(Fall):1-56.

Thomson, Janice. (1994) Mercenaries, Pirates, and Sovereigns: State-building and Extraterritorial Violence in Early Modern Europe. Princeton: Princeton University Press

Verkuil, Paul. (2007) Outsourcing Sovereignty: Why Privatization of Government Functions Threatens Democracy and What We Can Do about It: Why Privatization of Government Functions ... Democracy and What We Can Do About It. Cambridge: Cambridge University Press.

Zamparelli, Colonel Steven J. (1999) 'Competitive sourcing and privatization: Contractors on the battlefield'. Air Force Journal of Logistics, XXIII(3):1-17. 